\title{
Enhancing Coloration and Extending the Shelf Life of Plums While Alleviating Leaf Abscission by Utilizing Lisophosphatidylethanolamine and Oleic Acid
}

Farag, K. M. and S. M. Attia

Department of Horticulture (Pomology), Faculty of Agriculture, Damanhour University,

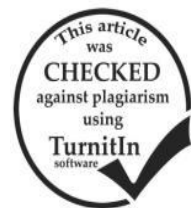
P.O.Box 22516, Damanhour, Egypt.

\begin{abstract}
Poor coloration of "Kelsey" plum fruits is considered one of the major problems that have been facing Egyptian growers, which hindered the expansion of "Kelsey" plum cultivation. Producers are in critical need to an effective treatment that enhances skin coloration while maintaining their keeping quality and their shelf life after harvest. Thus, the application of Ethrel, as an ethylene-releasing compound could increase anthocyanin content in plum skin. However, it has negative impact on leaf defoliation, yellowing in addition to its adverse effect on fruit storability. Thus, the objectives of this study were to enhance coloration of plums by using Ethrel before harvest in a new formulation to mitigate its damaging effects on leaves and fruits. Treatments included water as the control, Ethrel at $500 \mathrm{ppm}$ alone or in a combination with either lisophos or oleic acid in addition to Ethrel plus both lisophos at $400 \mathrm{ppm}$ and oleic acid at $400 \mathrm{ppm}$. Meanwhile, each of lisophos and oleic acid were applied individually. The results proved that the incorporation of both lisophos and oleic acid in one formulation with Ethrel mitigated the adverse effects of Ethrel on leaf abscission, leaf senescence and fruit shelf life and enhanced anthocyanin content in plums skin, in addition to prolonging their shelf life. Meanwhile, the incorporation of either lisophos or oleic acid to Ethrel resulted in greater anthocyanin content as compared with the control. Moreover, the formulation containing Ethrel plus both lisophos and oleic acid caused a significant increase in anthocyanin as compared with Ethrel alone or in the presence of either one of the two compounds. Furthermore, electrolyte leakage was significantly decreased in fruit tissue treated with Ethrel plus both lisophos and oleic acid. While lisophos alone resulted in the lowest percentage of such leakage of electrolytes in a consistent manner. In conclusion, this study provided an applicable solution to plum growers that could be adapted on a field scale to solve the problem of color enhancement without an associated leaf abscission or short shelf life by using Ethrel in a formulation containing lisophos and oleic acid.
\end{abstract}

Keywords: Plum, Coloration, Anthocyanin, Ethrel, LPE, Postharvest, Oleic acid, Leaf abscission.

Corresponding Author: Said M. Attia, Department of Horticulture, Faculty of Agriculture, Damanhour University, P.O.Box 22516, Damanhour, Egypt.E-mail address: attia.said@yahoo.com

\section{INTRODUCTION}

Plum fruit has important nutritional properties since it contains high percentage of fiber and sorbitol. It is also characterized with its antioxidant pigments (Kim et al., 2003 and Rozo-Romero et al., 2015). Skin color is the main quality attribute of plums. However, it is necessary to harvest plum early so they can withstand transport and handling which may reflect on less intense coloration (Abdi et al., 2002). Plums are also rich in some minerals such as phosphorus, calcium and potassium (Calvo-Villegas, 2009). To gain the required color, flavor and aroma that are demanded by consumers, plums must be picked at more advanced stage towards ripening (Louw and Theron, 2012). Thus, plum fruits producers have been facing the problem of obtaining well colored fruit that have the potential to market while delaying the loss of tissue firmness. Meanwhile, plum fruits are characterized by its high softening rate (Abdi et al., 1998).

Various plum cultivars show differences in their softening rate. Flesh firmness could be used as an index together with soluble solids contents to determine the appropriate stage of development at which the fruit could be tolerant to manipulation without compromising its required flavor (Manganaris et al., 2008). There are also great differences among plum cultivars regarding their antioxidant activity and capacity (Vizzotto et al., 2007). Besides, the skin anthocyanins, they have other groups of phenolic compounds known as the hydroxyl cinnamic acid derivatives such as chlorogenic acid, neochlorogenic acid and quercetin in addition to ascorbic acid in the peel and the flesh (Gil et al., 2002).
Although plums are the most numerous and diverse group of fruit tree species (Blazek, 2004), but the amount of research data does not reflect such abundance. The available information from conducted research on anthocyanins in plums is still limited.

There is a lack of information about the treatments that intensify plums color while avoiding undesired properties such as leaf abscission, loss of tissue firmness and short duration of the shelf life and storability. Excessive plum softening is a major factor limiting their shelf life. Such softening is the ripeningrelated process most sensitive to ethylene. Meanwhile, plums are classified as climacteric fruits. It was reported that there were two distinct types of plum ripening behavior for several cultivars (Zuzunaga et al., 2001). Some cultivars show a typical climacteric pattern while others have a suppressed climacteric. The latter group is characterized by low ethylene production until late stages of development, which is thought to be insufficient to coordinate ripening. In these cultivars, ethylene production may be suppressed 15- 500 fold compared with normal climacteric cultivars which was ascribed to an impaired ability of the fruit tissue to convert ACC into ethylene (Abdi et al., 1998- ElSharkawy et al., 2007).

Thus, several factors are involved in improving plum skin coloration and anthocyanin production depending on the cultivar, fruit position on the tree, shading fruit (Murray et al., 2005), nutrition supply from the mature leave (Martinez-Romero, 2003) in addition to foliar application of Ethrel. However, ethylene is a growth regulator that would pose negative impact on important physical properties of fruits such as 
size, weight and firmness. Furthermore, since it releases ethylene, it can drift and get absorbed by the leaves, causing yellowing and defoliation. This would adversely affect tree productivity in the current season and sprouting in the following season (Roberto et al., 2012).

Studies have provided evidence that LPE can accelerate ripening of cranberry fruits while prolong shelf-life at the same time (Farag and Palta, 1993b; Özgen et al., 2004). Furthermore, LPE treatment has also been found to reduce senescence of leaves, fruits and cut-flowers (Cowan, 2009; Farag and Palta, 1993 a; Hong et al., 2009 a; Kaur and Palta, 1997). LPE retards polygalacturonase-mediated fruit softening (Hong et al., 2008),

Plum growers in Egypt complain about poor coloration of fruits especially under arid conditions where trees have been exposed to heat stress and slight difference between day and night temperatures. They have been forced to quit the expansion of plum cultivation and even replaced already grown trees with other fruit species. In spite of the known quality parameters of "Kelsey" plums, its coloration is poor and producers are in critical need to an effective treatment that enhances skin coloration while maintaining their keeping quality and their shelf life after harvest. The application of Ethrel, as an ethylene-releasing compound, could increase anthocyanin content in plums skin. However, Ethrel causes a significant leaf abscission and accelerates leaf senescence as revealed from chlorophyll content and electrolyte leakage, in addition to its adverse effects on fruit storability (Roberto et al., 2012).

The objectives of this study were to enhance coloration of "Kelsey" plums before harvest while alleviating leaf abscission and maintaining the keeping quality of the fruits especially their shelf life. The influence of applying Ethrel as a commercial treatment was compared with Ethrel treatments in a new formulation to mitigate the damaging effects on fruits and leaves.

\section{MATERIALS AND METHODS}

The present study was carried out during the two consecutive seasons 2014 and 2015 using 5-years-old "Kelsey" plums (Prunus salicina L) budded on Marianna rootstock. Trees were spaced at $4 \times 5 \mathrm{~m} \mathrm{(4} \mathrm{m}$ between trees and $5 \mathrm{~m}$ between rows), grown in sandy soil under drip irrigation system in a private orchard at Elboustan region, Behira governorate, Egypt. Twenty eight uniform trees with similar vigor, healthy and free from defects were used for this investigation. Trees were sprayed to the run off using a hand sprayer on 9, 1 st July during 2014 and 2015, respectively by using the following treatments: control (water only), Ethrel (500 ppm), lisophos (400 ppm), oleic acid (400 ppm), Ethrel plus lisophos, Ethrel plus oleic acid in addition to Ethrel plus both lisophos and oleic acid at the same concentration of each compound alone. The trees received the treatment at one application date and the nonionic surfactant Top film at $0.05 \%(\mathrm{v} / \mathrm{v})$ was added to all treatments to reduce the surface tension of sprayed droplets. Studied treatments were arranged in a factorial experiment in a randomized complete block design. Four replications were used with each treatment and one tree represented one replication.

A random sample of 10 fruits/ replication was harvested for assessing fruit characteristics at harvest time. Similarly, other two samples, 10 fruits each, were picked for the assessment of the shelf life whether at ambient temperature $\left(22 \pm 2^{0}\right)$ or at House refrigeration at $\left(4-5^{0} \mathrm{C}\right)$ for seven days.

To investigate the effects of various treatments on vegetative system, the following properties were taken: four shoots (30- $45 \mathrm{~cm}$-long one-year-old) per tree were randomly selected and tagged to assess leaf drop percentage, electrolyte leakage, chlorophylls a and b. Chlorophylls a, b and ion leakage were assessed in two dates: the first time at harvest (July) and the second date at the end of season (mid-September). The leaves were placed in plastic bags and carefully transferred from the orchard to the laboratory to measure chlorophylls $\mathrm{a}, \mathrm{b}$ and ion leakage.

Physical properties were assessed as follow: the average fruit weight $(\mathrm{g})$ and the average fruit size $(\mathrm{cm} 3)$ was measured using a graduated cylinder of $1000 \mathrm{ml}$ containing tap water, fruit length $(\mathrm{cm})$ and fruit diameter $(\mathrm{cm})$ were measured using a Vernier caliper, the stones were extracted and weighted separately from the flesh while fruit firmness was determined as (Ib/in2) using Effigi pressure tester (mod. Ft327). Moreover, plum fruits were periodically weighed and the losses were recorded for each replicate. Data of weight losses were calculated as a percentage from the initial weight. Furthermore, electrolytes leakage of leaves and flesh (\%) were calculated as a ratio between the ion leakage before damage and total ion leakage by using the Conductivity meter. Plum leaves were counted and plum leaf abscissions (\%) were recorded for each replicate. Data of leaf abscission were calculated as a percentage from the initial leaf number. On the other hand, chemical characteristics were assessed as follow: TSS (\%) was determined in plum fruit juice using a hand refractometer, the acidity was detected calorimetrically based on estimated malic acid (A.O.A.C., 1985), total sugars were determined by using the phenol sulfuric acid method (Smith, 1956). Moreover, chlorophylls $\mathrm{a}, \mathrm{b}$ and Beta-carotene were determined according to (Lichtenthaler and Wellburn, 1985), aforementioned, by Manuela et al. (2012). Betacarotene in the flesh was determined according to the method of Mustapha and Babura (2009) while anthocyanin was assessed according to the method of Fuleki and Francis (1968). Moreover, at the end of the shelf life tests for 7 days, plum fruit quality was assessed as the final weight $(\mathrm{g})$ which was then used to determine the weight loss percentage. In addition, some physical and chemical parameters such as fruit firmness, TSS, acidity, TSS/ acidity ratio, chlorophylls a, b, carotenes and total sugars were determined. Data were analyzed as a normal and factorial arrangement in a randomized complete block design with four replicates. Comparisons among means were made via the least significant differences (LSD) at 0.05 levels according to Sendecor and Cochran (1980). The data were analyzed using SAS (2000). 


\section{RESULTS AND DISCUSSION \\ 1- Leaf vigor characteristics:}

The data concerning some vegetative characters of "Kelsey" plum trees as influenced by preharvest applications of Ethrel alone or in some formulations during the two seasons of 2014 and 2015 was reported in Table 1. Such data indicated that the only application that caused leaf abscission in both seasons was when Ethrel was applied alone. Furthermore, the application of either lisophos, oleic acid, or their formulations with Ethrel did not result in any leaf abscission in a consistent manner in both seasons. Thus, either lisophos, oleic acid or their combination with Ethrel were all able to mitigate the adverse effect of Ethrel on leaf abscission. Such leaves are needed as a source of carbohydrates for improving color formation in plums, as well as storing more carbohydrates in the main branches and roots. Moreover, floral induction and differentiation are in critical need to exported carbohydrates from the leaves to improve flowering and increase fruiting in the next season. Thus, many desirable effects could be obtained by either lisophos or oleic acid treatment such as the addition of lisophos with Ethrel mitigated the defoliation action of Ethrel, and delayed leaf and fruit senescence in cranberry (Farag and Palta 1991 c; 1993; Ozgen et al. 2005), LPE inhibited PLD (Phospholipases D) activity and that inhibition or lowering of PLD was associated with reduced ethylene evolution and delayed senescence (Ryu et al. 1997). On the other hand, ethylene accelerates senescence in the leaves of most species and promotes processes characteristics of leaf senescence such as decline in chlorophyll and photosynthesis, reduction in the level of proteins and starch, and increase in the activities of many hydrolytic enzymes (abeles et al., 1992). Moreover, Roberto et al., (2012) reported that spraying vine trees with Ethrel caused yellowing and defoliation. This would adversely affect vine productivity in the current season and sprouting in the following season.

To further prove the desired effect of lisophos and oleic acid, the percentage of leaf electrolyte leakage revealed that the greatest leakage was obtained with Ethrel-treated leaves as compared to the control and all other applied treatments before harvest in both seasons. However, no significant difference had obtained in the leakage of leaf electrolytes when they were treated with lisophos alone or oleic acid alone. In addition, when both natural compounds were individually combined with Ethrel, they resulted in similar values of electrolyte leakage, in both seasons. At the second sampling time, similar trend of results was obtained for leaf-electrolyte leakage since the greatest leakage was found with the application of Ethrel alone at $400 \mathrm{ppm}$ while the individual application of either lisophos or oleic acid caused a significant reduction of electrolyte leakage in addition to the ability of each used natural compound, namely lisophos and oleic acid, to alleviate the magnitude of such leakage caused by the incorporation of Ethrel in applied formulations during both seasons. The positive reported influence of lisophos or oleic acid could be due to reported explanation, as they maintain the plasma membrane integrity and mitigated the effect of ethylene on the cell wall or membranes lipid degradation (Farag and Palta, 1993 a). Both compounds were able to delay tissue senescence and extend the leaf vigor under field conditions. Moreover, LPE retarded polygalacturonase-mediated fruit softening (Hong et al., 2008), reduced activity of phospholipase D (PLD; EC 3.1.4.4) and membrane leakiness (Ryu et al., 1997; Hong et al., 2009 b).

Since chlorophyll content is an important parameter of leaf physiology, such content was taken as an important indicator to the progress towards senescence. In Table 1 leaf chlorophyll content was assessed during the two sampling times of mid-July and mid-September in both seasons. The data revealed that the highest chlorophylls $(\mathrm{a}, \mathrm{b})$ content was found in lisophos-treated leaves in both sampling times. However, oleic acid-treated leaves had similar chlorophyll a, b content in an identical manner to that found with the lisophos treatment in the second sampling date, only. Moreover, Ethrel-treated leaves had similar chlorophylls $(\mathrm{a}, \mathrm{b})$ in both sampling time to that found with the control. Meanwhile, the incorporation of either lisophos, oleic acid, or both with Ethrel solutions resulted in a significant delay in leaf, senescence in the first sampling date, since they all had more chlorophyll a, b in the leaf as compared with the control and Ethrel treatments. It was also evident that these trends in the second sampling time in the middle of September were, generally, similar to that obtained with chlorophylls $\mathrm{a}$ and $\mathrm{b}$ at the first sampling time. Aforementioned data emphasized that the two parameters of leaf physiology and the delay of leaf senescence, in response to various treatments, were consistent during the two sampling times which reflect on the current and next seasons fruiting. The above findings agreed with (Farag and Palta 1991b and 1993a: Özgen et al., 2015).

\section{2- Physical characteristics of fruits at harvest:}

The influence of various used treatment before harvest on some physical characteristics of plums was reported in Table 2 . The data indicated that there was a trend of a larger fruit size when treated with either lisophos or oleic acid was compared to Ethrel-treated fruit, in both seasons. However, the combinations of Ethrel with either oleic acid or lisophos resulted in similar fruit size in both seasons. Moreover, the formulation of Ethrel plus both lisophos and oleic acid gave no significant difference in fruit size from that of the control. Similar trend of results was obtained from fruit weight since the applications of lisophos alone or oleic acid alone led to greater fruit weight when compared with Ethrel-treated fruits in both seasons. However, when both compounds were combined with Ethrel in one formulation, there was a significant reduction in fruit weight relative to the use of each compound individually. The positive increase in both fruit size and weight at harvest could be attributed to the increase in leaf activity caused by lisophos or oleic acid which could reflect on enhancing the partitioning of more carbohydrates from the leaves to the plums, while ethylene released from Ethrel might cause the opposite trend to leaves since it reduces leaf activity. The role of LPE on fruit weight were presented by Özgen et al., (2015) who reported that preharvest applications of LPE resulted in significant improvement in both pomological 
and phytochemical attributes at harvest. LPE treatment led to a $17 \%$ increase in sweet cherry fruit weight at harvest as compared with control. On the other hand, Roberto et al., (2012) found that ethylene as a growth retardant would pose negative impact on important physical properties of the berries such as size, weight and firmness.

With regard to flesh weight at harvest, the data showed that there was a significant increase in flesh weight caused by lisophos alone or oleic acid, in both seasons, relative to the control and to Ethrel-treated fruits in a consistent manner. The addition of either lisophos or oleic acid to Ethrel tended to reduce flesh weight of plums at harvest except with Ethrel plus lisophos, in the second season. Furthermore, the formulation of Ethrel plus both lisophos and oleic acid resulted in a similar flesh weight to that of the control and to that obtained by Ethrel plus either lisophos or oleic acid separately, in both seasons. Stone weight of plums, on the other hand, was not significantly affected by various applied treatments as compared with the control in both seasons except with oleic acid alone that resulted in greater stone weight than the control, in the first season. This trend could be ascribed to the application dates of various treatments that followed the hardening of the stone or the endocarp. Similar trend of results was obtained with flesh/ stone ratio since the applications of various treatments did not affect flesh/ stone ratio at harvest when compared with the control, in both seasons.

Fruit length of "Kelsey" plum fruits as influenced by various applied treatments before harvest was determined and reported in Table 2. The data revealed that there was a trend of a larger fruit length when either lisophos or oleic acid was compared to Ethrel-treated fruits, in both seasons. Furthermore, the combinations of Ethrel plus either lisophos or oleic acid resulted in a similar manner to each other. On the other hand, when both compounds were combined with Ethrel in one formulation, there was a significant reduction in fruit length as compared with individual treatments. Response of fruit diameter to the application of various treatments at harvest was shown in Table 2. The data indicated that a significant decrease in fruit diameter caused by Ethrel-treatment in both seasons of study as compared with control. Other treatments gave inconsistent trend when compared with control and Ethrel treatments in both seasons. The above findings on both fruit length and fruit diameter agreed with Farag et al., (2012).

Table (1): Leaf physiological characteristics of "Kelsey" plum trees as influenced by various applied preharvest treatments during the two seasons 2014 and 2015.

\begin{tabular}{|c|c|c|c|c|c|c|c|c|c|c|c|c|c|c|}
\hline \multirow{3}{*}{ Treatments } & & & \multirow{2}{*}{\multicolumn{2}{|c|}{$\begin{array}{c}\text { First sample* } \\
\text { Leaf } \\
\text { Electrolyte } \\
\text { leakage }(\%)\end{array}$}} & \multirow{2}{*}{\multicolumn{2}{|c|}{$\begin{array}{c}\text { Second sample } \\
\text { Leaf } \\
\text { Electrolyte } \\
\text { leakage }(\%)\end{array}$}} & \multicolumn{4}{|c|}{ First sample } & \multicolumn{4}{|c|}{ Second sample* } \\
\hline & \multicolumn{2}{|c|}{$\begin{array}{c}\text { Leaf } \\
\text { abscission (\%) }\end{array}$} & & & & & \multicolumn{2}{|c|}{$\begin{array}{c}\text { Leaf } \\
\text { Chlorophyll a } \\
(\mathrm{mg} / \mathbf{1 0 0} \mathrm{g})\end{array}$} & \multicolumn{2}{|c|}{$\begin{array}{c}\text { Leaf } \\
\text { Chlorophyll b } \\
(\mathrm{mg} / 100 \mathrm{~g})\end{array}$} & \multicolumn{2}{|c|}{$\begin{array}{c}\text { Leaf } \\
\text { Chlorophyll a } \\
(\mathrm{mg} / \mathbf{1 0 0} \mathrm{g})\end{array}$} & \multicolumn{2}{|c|}{$\begin{array}{c}\text { Leaf } \\
\text { Chlorophyll b } \\
(\mathrm{mg} / 100 \mathrm{~g})\end{array}$} \\
\hline & 2014 & 2015 & 2014 & 2015 & 2014 & 2015 & 2014 & 2015 & 2014 & 2015 & 2014 & 2015 & 2014 & 2015 \\
\hline Control & $0 \mathrm{~b}$ & $0 \mathrm{~b}$ & $38.68 \mathrm{~b}$ & $30.5 \mathrm{~b}$ & $35.95 \mathrm{~b}$ & $30 \mathrm{~b}$ & $14.05 \mathrm{c}$ & $15.77 \mathrm{c}$ & $4.78 \mathrm{c}$ & $4.8 \mathrm{c}$ & $4.66 \mathrm{~b}$ & $5.02 \mathrm{c}$ & $1.67 \mathrm{~b}$ & $1.62 \mathrm{c}$ \\
\hline Ethrel 500 ppm & $7.1 \mathrm{a}$ & $9.37 \mathrm{a}$ & $42.26 \mathrm{a}$ & $35 \mathrm{a}$ & $45.55 \mathrm{a}$ & $35 \mathrm{a}$ & $14.39 \mathrm{c}$ & $14.98 \mathrm{c}$ & $4.89 \mathrm{c}$ & $4.56 \mathrm{c}$ & $4.49 \mathrm{~b}$ & $4.35 \mathrm{c}$ & $1.6 \mathrm{~b}$ & $1.4 \mathrm{c}$ \\
\hline Lisophos 400 ppm & $0 \mathrm{~b}$ & $0 \mathrm{~b}$ & $26.46 \mathrm{~d}$ & $22.8 \mathrm{~d}$ & $26.94 \mathrm{~d}$ & $21.5 \mathrm{e}$ & $20.61 \mathrm{a}$ & $20.36 \mathrm{a}$ & $7.01 \mathrm{a}$ & $6.19 \mathrm{a}$ & $9.12 \mathrm{a}$ & $9.5 \mathrm{a}$ & $3.27 \mathrm{a}$ & $3.1 \mathrm{a}$ \\
\hline Oleic acid 400 ppm & $0 \mathrm{~b}$ & $0 \mathrm{~b}$ & $27.55 \mathrm{~d}$ & $24 \mathrm{~d}$ & $21.94 \mathrm{e}$ & $24 \mathrm{~d}$ & $19.18 \mathrm{~b}$ & $18.84 b$ & $6.53 \mathrm{~b}$ & $5.74 \mathrm{~b}$ & $7.93 \mathrm{a}$ & $9.59 \mathrm{a}$ & $2.84 \mathrm{a}$ & $3.1 \mathrm{a}$ \\
\hline Ethrel+ Lisophos & $0 \mathrm{~b}$ & $0 \mathrm{~b}$ & $31.52 \mathrm{c}$ & $29 \mathrm{bc}$ & $31.9 \mathrm{c}$ & $25 \mathrm{~d}$ & $19.47 \mathrm{~b}$ & $19.32 \mathrm{a}$ & $6.62 \mathrm{~b}$ & $5.88 \mathrm{ab}$ & $8.15 \mathrm{a}$ & $8.26 \mathrm{ab}$ & $2.92 \mathrm{a}$ & $2.66 \mathrm{ab}$ \\
\hline Ethrel+ Oleic acid & $0 \mathrm{~b}$ & $0 \mathrm{~b}$ & $31.56 \mathrm{c}$ & $28 \mathrm{c}$ & $30.9 \mathrm{c}$ & $27.5 \mathrm{c}$ & $20.47 \mathrm{a}$ & $20.13 \mathrm{ab}$ & $6.96 \mathrm{a}$ & $6.13 \mathrm{ab}$ & $8.49 \mathrm{a}$ & $7.92 \mathrm{~b}$ & $3.2 \mathrm{a}$ & $2.55 \mathrm{~b}$ \\
\hline Ethrel+ Lisophos + Oleic acid & $0 \mathrm{~b}$ & $0 \mathrm{~b}$ & $31.63 \mathrm{c}$ & $28.3 \mathrm{c}$ & $30.8 \mathrm{c}$ & $25.3 \mathrm{~d}$ & $20.67 \mathrm{a}$ & $19.68 \mathrm{ab}$ & $7.03 \mathrm{a}$ & $5.99 \mathrm{ab}$ & $9.05 \mathrm{a}$ & $8.72 \mathrm{ab}$ & $3.24 \mathrm{a}$ & $2.81 \mathrm{ab}$ \\
\hline
\end{tabular}

* First and second sampling was done in (mid-July and mid-September) during 2014 and 2015 seasons, respectively.

*Values, within a column, of similar letters are not significantly different according to the least significant difference (LSD) at 0.05 levels.

Table (2): Physical characteristics of "Kelsey" plums at harvest as influenced by various applied preharvest treatments during the two seasons 2014 and 2015.

\begin{tabular}{|c|c|c|c|c|c|c|c|c|c|c|c|c|c|c|}
\hline \multirow[t]{2}{*}{ Treatments } & \multicolumn{2}{|c|}{$\begin{array}{l}\text { Fruit size* } \\
\quad(\mathrm{cm} 3)\end{array}$} & \multicolumn{2}{|c|}{$\begin{array}{l}\text { Fruit weight* } \\
\text { (g) }\end{array}$} & \multicolumn{2}{|c|}{$\begin{array}{l}\text { Flesh weight* } \\
\text { (g) }\end{array}$} & \multicolumn{2}{|c|}{$\begin{array}{l}\text { Stone weight* } \\
\text { (g) }\end{array}$} & \multicolumn{2}{|c|}{$\begin{array}{c}\text { Flesh/ stone } \\
\text { ratio }\end{array}$} & \multicolumn{2}{|c|}{$\begin{array}{l}\text { Fruit length } \\
\text { (cm) }\end{array}$} & \multicolumn{2}{|c|}{$\begin{array}{l}\text { Fruit diameter } \\
\text { (cm) }\end{array}$} \\
\hline & 2014 & 2015 & 2014 & 2015 & 2014 & 2015 & 2014 & 2015 & 2014 & 2015 & 2014 & 2015 & 2014 & 2015 \\
\hline Control & $402.54 \mathrm{~b}$ & $355.58 \mathrm{bcd}$ & $408.18 \mathrm{~b}$ & $360.56 \mathrm{bcd}$ & $396.68 \mathrm{~b}$ & $350.06 \mathrm{bc}$ & $11.5 \mathrm{bc}$ & $10.5 \mathrm{a}$ & $36.54 \mathrm{a}$ & $33.38 \mathrm{a}$ & $4.37 \mathrm{ab}$ & $4.1 \mathrm{a}$ & $4.19 \mathrm{a}$ & $3.9 \mathrm{a}$ \\
\hline Ethrel 500 ppm & $370.61 \mathrm{c}$ & $329.06 \mathrm{~d}$ & $376.25 \mathrm{c}$ & $344.04 \mathrm{~d}$ & $365.25 \mathrm{c}$ & $323.54 \mathrm{c}$ & $11 \mathrm{c}$ & $10.5 \mathrm{a}$ & $33.3 \mathrm{a}$ & $31.34 \mathrm{a}$ & $4.19 \mathrm{~cd}$ & $3.83 \mathrm{ab}$ & $4.1 \mathrm{c}$ & $3.7 \mathrm{~b}$ \\
\hline Lisophos $400 \mathrm{ppm}$ & $445.97 \mathrm{a}$ & $392.51 \mathrm{ab}$ & $451.61 \mathrm{a}$ & $397.4 \mathrm{ab}$ & 439.36 a & 385.99 a & $12.25 \mathrm{ab}$ & $11.5 \mathrm{a}$ & $36.1 \mathrm{a}$ & $33.62 \mathrm{a}$ & $4.46 \mathrm{a}$ & $4.12 \mathrm{a}$ & $4.13 \mathrm{abc}$ & $3.82 \mathrm{ab}$ \\
\hline Oleic acid 400 ppm & $452.25 \mathrm{ab}$ & $401.21 \mathrm{a}$ & $457.89 \mathrm{a}$ & 406.19 a & $444.64 \mathrm{a}$ & $395.1 \mathrm{a}$ & $13.25 \mathrm{a}$ & $11 \mathrm{a}$ & $33.74 \mathrm{a}$ & $36.13 \mathrm{a}$ & $4.44 \mathrm{a}$ & $4.1 \mathrm{a}$ & $4.14 \mathrm{abc}$ & $3.8 \mathrm{ab}$ \\
\hline Ethrel+ Lisophos & $417 \mathrm{~b}$ & $370.66 a b c$ & $422.64 \mathrm{~b}$ & $375.64 \mathrm{abc}$ & $410.64 \mathrm{~b}$ & $365.04 \mathrm{ab}$ & $12 \mathrm{bc}$ & $10.6 \mathrm{a}$ & $34.46 \mathrm{a}$ & $34.72 \mathrm{a}$ & $4.3 \mathrm{bc}$ & $3.95 \mathrm{ab}$ & $4.13 \mathrm{abc}$ & $3.77 \mathrm{ab}$ \\
\hline Ethrel+ Oleic acid & $405.75 \mathrm{~b}$ & $352.49 \mathrm{~cd}$ & $411.34 \mathrm{~b}$ & $357.47 \mathrm{~cd}$ & $399.14 \mathrm{~b}$ & $345.97 \mathrm{bc}$ & $12.25 \mathrm{ab}$ & $11.5 \mathrm{a}$ & $32.66 \mathrm{a}$ & $30.12 \mathrm{a}$ & $4.25 \mathrm{bcd}$ & $3.97 \mathrm{ab}$ & $4.15 \mathrm{ab}$ & $3.89 \mathrm{ab}$ \\
\hline Ethrel+ Lisophos + Oleic acid & $399.3 \mathrm{~b}$ & $344.05 \mathrm{~cd}$ & $404.54 \mathrm{~b}$ & $349.03 \mathrm{~cd}$ & $393.69 \mathrm{~b}$ & $339.53 \mathrm{bc}$ & $11.25 \mathrm{bc}$ & $9.5 \mathrm{a}$ & $35.3 \mathrm{a}$ & $35.85 \mathrm{a}$ & $4.15 \mathrm{~d}$ & $3.81 \mathrm{~b}$ & $4.1 \mathrm{bc}$ & $3.8 \mathrm{ab}$ \\
\hline
\end{tabular}


Assessing the shelf parameters as influenced by the treatments after the incorporation of plum fruits at refrigerator and ambient temperature for 7 days on weight loss $\%$ of plums was reported in Table 3 . The data indicated that the greatest weight loss was obtained with the application of Ethrel at 400 ppm as compared with all other applied treatments, in both seasons. On the other hand, the individual application of either lisophos or oleic acid caused a significant reduction of weight loss. Moreover, the incorporation of either lisophos or oleic acid individually with Ethrel treatment mitigated the adverse effect of Ethrel on weight loss. Furthermore, when both compounds were combined with Ethrel in one formulation, there was a significant reduction in weight loss than control and Ethrel treatments. The positive influence of lisophos or oleic acid could be explained by maintaining the plasma membrane due to these treatments (Farag et al., 2011); both compounds were able to decrease weight loss. Moreover, weight loss percentage at the end of shelf life of "Kelsey" plum fruits after 7 days as influenced by the interaction between preharvest applied treatments and the two types of assessing the shelf life was reported in Table 4. The data revealed that there was a significant increase in weight loss $\%$ between storage fruit at $4-5^{0}$ $\mathrm{C}$ and storage at $22 \pm 2^{0} \mathrm{C}$ whether in the control or treated fruits in both seasons. Moreover, the highest rate of weight loss was caused by storage at ambient temperature. However, after 7 days of storage, all treatments except Ethrel led to a significant decline in fruit weight loss, in both seasons, as compared with the control. Meanwhile, the application of either lisophos or oleic acid was capable of retarding the rate of weight loss. Moreover, when both compounds were combined with Ethrel in one formulation, there was a significant reduction in weight loss as compared with Ethrel-treated fruits after 7 days of storage in both seasons. Since unsaturated fatty acids such as oleic acid maintain the fluidity of plasma membrane and its integrity, they could alleviate the damaging effect of ethylene on fruit senescence, and halt the progress toward senescence.

The senescence of floral tissues was accompanied by a decrease in the levels of polar lipids and a decrease in their synthesis (Sylvester and Paulin, 1987- Ahmed and Palta, 2011). The effect of lisophos and oleic acid on the shelf life whether alone or when incorporated with Ethrel could be attributed to their effect on the membrane integrity which led to retarding the aging and senescence of plum fruits, maintaining the fruit health and mitigating the adverse effects of Ethrel on the membrane and cell wall structure (Attia, 2009). Meanwhile, low-temperature storage is beneficial in slowing the ripening processes in plums by reducing ethylene production, respiration rate, cell wall degradation, softening and extending shelf life (Crisosto et al., 2007; Guerra and Casquero, 2008 : Díaz-Mula et al., 2009 and Kader, 2003). On the other hand, RozoRomero et al., (2015) reported that plum fruits treated with ethylene were stored at room temperature for 9 days had a significant increase in the respiration index and fresh mass loss in the plum fruits.
Table(3):Effects of preharvest application of Ethrel, lisophos and oleic acid on fruit weight loss $(\%)$ of "Kelsey" plum fruits after 7 days of storage during the two seasons 2014 and 2015.

\begin{tabular}{lcc}
\hline \multicolumn{3}{c}{ Weight loss \% } \\
Treatments & $\mathbf{2 0 1 4}$ & $\mathbf{2 0 1 5}$ \\
\hline Control & $6.14 \mathrm{~b}$ & $6.05 \mathrm{a}$ \\
Ethrel $500 \mathrm{ppm}$ & $6.51 \mathrm{a}$ & $6.09 \mathrm{a}$ \\
Lisophos $400 \mathrm{ppm}$ & $2.64 \mathrm{~d}$ & $2.65 \mathrm{cb}$ \\
Oleic acid $400 \mathrm{ppm}$ & $2.35 \mathrm{e}$ & $2.35 \mathrm{~d}$ \\
Ethrel+ Lisophos & $2.55 \mathrm{~d}$ & $2.66 \mathrm{~b}$ \\
Ethrel+ Oleic acid & $2.89 \mathrm{c}$ & $2.44 \mathrm{~cd}$ \\
Ethrel+ Lisophos + Oleic acid & $2.27 \mathrm{e}$ & $2.4 \mathrm{~d}$
\end{tabular}

\footnotetext{
*Values, within a column, of similar letters are not significantly different according to the least significant difference (LSD) at 0.05 levels.
}

Table(4):Weight loss \% of "Kelsey "plum fruits as influenced by the interaction between applied treatments and storage type during the two seasons 2014 and 2015.

\begin{tabular}{lcccc}
\hline & \multicolumn{2}{c}{$\mathbf{2 0 1 4}$} & \multicolumn{2}{c}{2015} \\
Treatments & $\begin{array}{c}\text { Shelf life assessment } \\
\text { Refrigerated }\end{array}$ & $\begin{array}{c}\text { At ambient } \\
\text { temperature }\end{array}$ & $\begin{array}{c}\text { Shelf life assessment } \\
\text { Refrigerated }\end{array}$ & $\begin{array}{c}\text { At ambient } \\
\text { temperature }\end{array}$ \\
\hline Control & $4.71 \mathrm{~b}$ & $7.57 \mathrm{a}$ & $4.45 \mathrm{~b}$ & $7.64 \mathrm{a}$
\end{tabular}

$\begin{array}{lcccc}\text { Ethrel } 500 \mathrm{ppm} & 4.49 \mathrm{~b} & 8.54 \mathrm{a} & 4.28 \mathrm{~b} & 7.9 \mathrm{a} \\ \text { Lisophos } 400 \mathrm{ppm} & 2.2 \mathrm{cde} & 3.08 \mathrm{bcde} & 1.99 \mathrm{~cd} & 3.32 \mathrm{bc} \\ \text { Oleic acid } 400 \mathrm{ppm} & 1.68 \mathrm{de} & 3.03 \mathrm{bcde} & 1.47 \mathrm{~d} & 3.23 \mathrm{bc} \\ \text { Ethrel+ Lisophos } & 1.05 \mathrm{e} & 4.06 \mathrm{bc} & 1.08 \mathrm{~d} & 4.25 \mathrm{~b} \\ \text { Ethrel+ Oleic acid } & 1.61 \mathrm{de} & 4.18 \mathrm{bc} & 1.39 \mathrm{~d} & 3.59 \mathrm{bc} \\ \text { Ethrel+ Lisophos + } & 1.1 \mathrm{e} & 3.45 \mathrm{bcd} & 1.41 \mathrm{~d} & 3.39 \mathrm{bc} \\ \text { Oleic acid } & & \end{array}$

*Values, within columns of each year, of similar letters are not significantly different according to the least significant difference (LSD) at 0.05 levels.

The influence of various used treatments before harvest on some physical and chemical characteristics of freshly harvested plums compared to refrigerated or kept at room temperature for 7 days during season 2014 and 2015 was assessed and reported in Table 5. The data presented that treated fruits with Ethrel had significantly lower fruit firmness at harvest than that found in the control while both lisophos and oleic acidtreated fruits had significantly higher firmness than that of the control and other treatments. These trends were consistent during the two seasons. On the other hand, both lisophos and oleic acid-treated fruits had significantly greater flesh firmness at harvest and at the end of shelf life as compared with those with those treated with Ethrel ones in both seasons. Moreover the incorporation of either lisophos or oleic acid with Ethrel and the formulation of Ethrel plus both lisophos and oleic acid resulted in mitigating the adverse effect of Ethrel alone on fruit firmness in both seasons of study. To explain the role of Ethrel on fruit firmness, Drake et al., (2006) treated 'Scarletspur Delicious' and 'Gale 
Gala' apple trees preharvest with Ethrel and evaluated fruit response at harvest. They found that Ethrel intensified starch loss, ethylene production, and reduced firmness. On the other hand, the role of oleic acid on fruit firmness could be due to the role of fatty acids in determining the properties of cellular membranes, such as membrane permeability, fluidity and rigidity (Maxfield and Tabas, 2005). Maintaining the membrane integrity by oleic acid could activate sucrose and calcium transport which reflect on retarding the cell wall hydrolysis (Attia, 2009). It has been found that in a ripened fruit, LPE inhibited ethylene production to prolong shelf life and maintain fruit firmness. While, retards polygalacturonase, mediated fruit softening (Hong et al., 2008), membrane leakiness (Hong et al., $2009 \mathrm{~b}$ ) and the inhibition of lipid breakdown by LPE, resulting in the protection of membrane integrity during ripening or senescence, is expected based on its inhibitory activity against PLD (Ryu et al., 1997).

Electrolyte leakage data of "Kelsey" plum cultivar as influenced by preharvest treatments with Ethrel, lisophos and oleic acid after 7 days of shelf life was reported in Table 5. The results proved that the greatest leakage was obtained with Ethrel-treated fruits as compared to the control and all other applied treatments before harvest in both seasons. Meanwhile, the individual application of either lisophos or oleic acid caused a significant reduction of electrolyte leakage. In addition, when both natural compounds were individually combined with Ethrel, they resulted in reduction of electrolyte leakage of fruits. On the other hand, the formulation of Ethrel plus both lisophos and oleic acid resulted in a significant decrease in electrolyte leakage of fruit as compared with individual application of either lisophos or oleic acid or to Ethrel alone in both seasons of study. The resulted increase in electrolyte leakage by Ethrel, as an ethylene releasing compound could accelerate fruit deterioration and senescence, while the reduction in electrolyte leakage by lisophos or oleic acid might to be attributed to retarding senescence of leaves and fruits (Cowan, 2009; Farag and Palta, 1993 a; Hong et al., 2009 a). Moreover, LPE-treated banana fruit may improve shelf life by maintaining membrane integrity, reducing respiration, and slowing the breakdown of starch and cell walls during ripening and senescence of banana fruit tissue. Results of the experiments indicated that a postharvest dip treatment with LPE may improve shelf life of banana fruit by 1 to 2 days (Zienab et al., 2015).

Changes in total soluble solids (TSS) in "Kelsey" plums in response to various applied treatments after 7 days of storage were reported in Table 5. The data indicated that treated plums with Ethrel had higher TSS content than that of lisophos, oleic acid and control. In both seasons, lisophos and oleic acid treated plums did not have a significant change in TSS as compared with the control. Moreover, when both compounds were combined with Ethrel in one formulation gave a significant increase in TSS as compared with control or with the individual application of lisophos and oleic acid in both seasons. Furthermore, the addition of Ethrel with both lisophos and oleic acid resulted in increasing TSS similar to Ethrel alone, especially in the first season. The increase in fruit TSS of plums found in this study agreed with the findings of (Attia, 2009).

The influence of various treatments after 7 days of shelf life on acidity of "Kelsey" was reported in Table 5. The data showed that there was a significant reduction in fruit acidity by Ethrel treatment relative to the control in both seasons. However, there was a significant increase in fruit acidity, when plum fruits were treated with either lisophos or oleic acid. Furthermore, combinations of Ethrel plus either lisophos or oleic acid resulted in a reduction in acidity compared to control or lisophos-treated fruits. The above trend of fruit acidity agreed with those reported by Drake et al., (2005).

Preharvest applications of various used treatment were reported in Table 5 in terms of their influence on TSS/ acidity after 7 days of shelf life. The data provided evidence that there was an enhancement of "Kelsey" plums ripening by the application of Ethrel as an important parameter indicated. The increase in TSS/ acidity ratio was significant in both seasons by Ethrel treatment compared with the control. Meanwhile, there was no significant difference between Ethrel-treated fruits and Ethrel-containing formulations such as Ethrel plus lisophos or oleic acid. Even though, the influence of either lisophos or oleic acid alone on TSS/acidity tended to decrease such ratio as compared with Ethrel alone. Thus, Ethrel impact on the TSS/ acidity was dominant regardless it was applied alone or in a combination with either lisophos or oleic acid. The above findings agreed with those reported by (Farag et al., 2010, 2011, and 2012).

The influence of preharvest applications of various used treatments was reported in Table 5 in terms of their influence on total sugars in "Kelsey" plums after 7 days of shelf life. The data provided evidence that there was a significant increase in total sugars by Ethrel treatment in both seasons relative to the control. However, the applications of either lisophos or oleic acid did not have a significant impact on total sugars of "Kelsey" cultivar in a consistent manner as compared with control. Moreover, Ethrel-treated fruits had significant increase in total sugars when compared with those of lisophos or oleic acid-treated fruits. In the meantime, the total sugars content didn not significantly vary between lisophos and oleic acid-treated fruits. When the values of total sugars in fruits treated with either Ethrel alone or in the presence of lisophos, the data revealed that lisophos-treated fruits had significantly lower amount of total sugars than that treated with the combination of Ethrel plus lisophos. Thus, Ethrel-treated fruits had superior amount of total sugars, but the incorporation of either lisophos or oleic acid with Ethrel didn't lead to further elevation to the level of total sugars in the fruits in both seasons. The above trend of fruit total sugars agreed with those reported by (Attia, 2009).

Changes in anthocyanin content of "Kelsey" plums after shelf life were reported in Table 5. The data indicated that the highest anthocyanin content was found in Ethrel-treated fruits. However, lisophos-treated fruits resulted in similar anthocyanin content in an identical manner to that found with oleic acid treatments. Meanwhile, the incorporation of either 
lisophos or oleic acid or both with Ethrel solutions resulted in a significant increase in anthocyanin content. They all had more anthocyanin in the fruit as compared with the control or with both lisophos and oleic acid treatments. On the other hand, when both compounds were combined with Ethrel in one formulation resulted in a significant difference in anthocyanin content than Ethrel alone or individually added to Ethrel. Since anthocyanin content in plum fruit is a main quality attribute, the preference of one of these effective treatments on anthocyanins would depend upon the other quality parameters such as fruit firmness, fruit size and weight, pulp to stone ratio and later on the shelf life test. Ethrel, as an ethylene releasing compound, activated the formation of anthocyanin. However, Ethrel led to the reduction of fruit shelf life which is another important quality attribute. The results of this study were in line with other studies such as Özgen et al., (2015). LPE can accelerate ripening of fruits and prolong shelf-life at the same time. Preharvest applications of LPE resulted in significant improvement in both pomological and phytochemical attributes at harvest. LPE treatment led to a $27 \%$ and $16 \%$ more anthocyanin than the control. LPE treatment has also been found to increase anthocyanin accumulation (Hong, 2008), and stimulate ethylene synthesis (Hong et al., 2008). Moreover, Cheng et al., (2015) ethylene treatment significantly enhanced the anthocyanin accumulation in plum fruit peel. Furthermore, LPE inhibits PLD and is reported to affect the activity of enzymes relevant for producing quality, such as PAL and acid invertase. Stimulation of ripening in nonclimateric table grape (Hong et al., 2007). Increased activity of ACO (1-aminocyclopropane-1-carboxylic acid oxidase) (Hong et al., 2002). Where 18:0-LPE enhanced the activity of PAL and insoluble AcInv (Hong et al., 2007; Hong et al., 2009 b). Color improvement in LPE-treated fruits has been attributed to enhanced PAL activity and anthocyanin accumulation (Farag and Palta, 1991 c; Özgen et al., 2004). When LPE was reported to enhance ethylene production (Farag and Palta, 1989) and improve the effectiveness of Ethrel on cranberry fruit (Farag and Palta, 1989 b).

The response of chlorophyll a content in "kelsey" plums to Ethrel, lisophos and oleic acid after 7 days of shelf life was reported in Table 5 revealed that the significant reduction in chlorophyll a at harvest in "Kelsey" fruit skin was found in Ethrel-treated ones as compared with the control. Similar trend of results was obtained with the combination of Ethrel plus either lisophos or oleic acid since chlorophyll a content was significantly lower than that found in the control fruit. Moreover, the combination of Ethrel with either lisophops or oleic acid resulted in reduction chlorophyll a content in fruit skin at harvest in both seasons. Furthermore, both either lisophos or oleic acid treatment caused a significant reduction in chlorophyll a when compared with the control. Similar trend of results was obtained with chlorophyll b. The above findings whether for chlorophyll a or b agreed with Attia, (2009 and 2013). Furthermore, Huybrechts et al., (2003) reported that Ethrel enhanced ethylene production and stimulated progressive loss of chlorophyll.

Changes in Carotene content in "Kelsey" plums after shelf life in response to preharvest application of various used treatments were reported in Table 5. The data showed that carotenes were drastically increased by Ethrel, lisophos, oleic acid, Ethrel plus lisophs and Ethrel plus both lisophos and oleic acid as compared with the control in both seasons. Moreover, there was further added advantage from the incorporation of lisophos and oleic acid along with Ethrel as compared with Ethrel alone. However, lisophos alone or oleic acid individually caused a significant increase in carotenes relative to control. The increase in the conversion of chloroplasts to chromoplasts was also reported as a result of the increase of ethylene content in fruits (BenArieh and Guelfat-Reich., 1975) and (Huybrechts et al., 2003), they reported that Ethrel enhanced ethylene production and stimulated progressive loss of chlorophyll and gain of carotenoids. On the other hand, the increase in carotenes by oleic acid treatment could be due to its moderate stimulation of ethylene production for a relatively short time as in the case with mild stress-induced ethylene (Farag et al., 2012). Moreover, color improvement in LPE-treated fruits has been attributed to enhanced carotenoid accumulation (Kang et al., 2003).

Table (5): The influence of various used treatments before harvest on some physical and chemical characteristics of plums at harvest, refrigerator $\left(4-5^{0} \mathrm{C}\right)$ and room temperature $\left(22 \pm 2^{0} \mathrm{C}\right)$ at the end of shelf life (after 7 days) during the two seasons 2014 and 2015.

\begin{tabular}{|c|c|c|c|c|c|c|c|c|c|c|c|c|c|}
\hline \multirow[t]{2}{*}{ Treatments } & \multirow{2}{*}{$\begin{array}{c}\begin{array}{c}\text { Firmness } \\
\left(\mathrm{Lb} / \mathrm{in}^{2}\right)\end{array} \\
20142015 \\
\end{array}$} & \multirow{2}{*}{$\begin{array}{c}\text { Electrolyte } \\
\text { leakage }(\%) \\
20142015\end{array}$} & & \multirow{2}{*}{$\begin{array}{c}\text { Acidity } \\
(\%) \\
20142015\end{array}$} & \multirow{2}{*}{$\begin{array}{c}\text { TSS/ } \\
\text { Acidity } \\
\text { ratio } \\
20142015\end{array}$} & \multirow{2}{*}{ 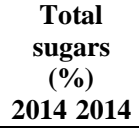 } & \multirow{2}{*}{$\begin{array}{c}\begin{array}{c}\text { Anthocyanin } \\
\text { (mg/ 100 g) }\end{array} \\
2015 \quad 2014 \\
\end{array}$} & \multirow{2}{*}{\multicolumn{2}{|c|}{$\begin{array}{r}\text { Chlorophyll } \\
\text { a (mg/ } 100 \text { g) } \\
2015 \quad 2014 \\
\end{array}$}} & \multirow{2}{*}{\multicolumn{2}{|c|}{$\begin{array}{r}\text { Chlorophyll } \\
\text { b (mg/ 100 g) } \\
2015 \quad 2014 \\
\end{array}$}} & \multirow{2}{*}{\multicolumn{2}{|c|}{$\begin{array}{c}\text { Carotene } \\
(\mathrm{mg} / 100 \mathrm{~g}) \\
2015 \quad 2014 \\
\end{array}$}} \\
\hline & & & 0142015 & & & & & & & & & & \\
\hline on & $13.1 \mathrm{~b} \quad 13.2 \mathrm{~b}$ & $66.08 \mathrm{~b} 58.19 \mathrm{~b}$ & $11.96 \mathrm{c} 12.36 \mathrm{c}$ & 1.55 a $1.23 \mathrm{c}$ & $7.9 \mathrm{c} \quad 9.46 \mathrm{~d}$ & $7.46 \mathrm{c} 7.6 \mathrm{c}$ & $4.66 \mathrm{e} \quad 4.36 \mathrm{e}$ & & & $0.965 \mathrm{a}$ & & $0.552 \mathrm{f}$ & f $0.45 \mathrm{e}$ \\
\hline Ethre & 7.74 e $7.56 \mathrm{e}$ & & 14.18 a 14 & & $11.2 \mathrm{a} 11.89 \mathrm{a}$ & $9.09 \mathrm{a} 9.51 \mathrm{a}$ & & & & & & & \\
\hline $0 \mathrm{ppm}$ & 15.79 a 16 a & & $12 \mathrm{c}$ & & $8.1 \mathrm{c} \quad 8.44 \mathrm{e}$ & & & & & & & & \\
\hline leic & $16.38 \mathrm{a} 16.68 \mathrm{a}$ & & $12 \mathrm{e} \quad 12.2$ & & $8.28 \mathrm{c} 9.49 \mathrm{~d}$ & $8 c 7.55 c$ & & & & & & & \\
\hline hos & $10.5 \mathrm{~d} \quad 10.7 \mathrm{~d}$ & 152. & $13.8 \mathrm{~b} \quad 14.4$ & & $10.5 \mathrm{~b} 11.8 \mathrm{ab}$ & 8.8 b $9.16 b$ & & & & & & & \\
\hline threl+ Oleic acid & $11.28 \mathrm{c} 11.4 \mathrm{~cd}$ & $61.67 \mathrm{c} 51.12 \mathrm{c}$ & $13.9 \mathrm{~b} 14.7$ & 1.29 & 10.9 ab 11 & 8.86 b 9.4 & & 1.82 & $1.86 \mathrm{c}$ & $0.57 \mathrm{c}$ & $0.51 \mathrm{c}$ & $1.09 \mathrm{c}$ & $1.09 \mathrm{~b}$ \\
\hline $\begin{array}{l}\text { Ethrel+ Lisophos } \\
+ \text { Oleic acid }\end{array}$ & & & & & & $9 a b$ & 28 & & 1.3 & 0.39 & 0.35 & 1.2 & \\
\hline
\end{tabular}

*Values, within a column, of similar letters are not significantly different according to the least significant difference (LSD) at 0.05 levels. 


\section{REFERENCES}

A. O. A. C. (1985). Official Methods of Analysis of the Association of Official Analytical Chemists. Washington D C, USA, 14 Th Ed.

Abdi, N., P. Holford and B. Mcglasson. (2002). Application of two dimensional gel electrophoresis to detect proteins associated with harvest maturity in stonefruit. Postharvest Biol. Technol. 26, 1-13.

Abdi, N.; McGlasson, W.B.; Holford, P.; Williams, M.; Mizrahi, Y. (1998). Responses of climacteric and suppressed-climateric plums to treatment with propylene and 1-methylcyclopropene. Postharvest Biology and Technology.14: 29-39.

Abeles, F.B; Morgan, P.W; and Saltveit, Jr, M. (1992). Ethylene in Plant Biology .Academic Press, Inc. New York. USA. PP. 414.

Ahmed, Z. F. A. and Palta, J. P. (2011). Hormone-like effect of a natural lipid, lysophosphatidylethanolamine, can mitigate calcium deficiency injury in potato shoot cultures. HortScience 46: 196. (Abstr.).

Attia, S.M. (2009). Effect of some preharvest treatments on quality and ripening of "Canino" apricot fruits and on their shelf life. M.Sc. Faculty of AgricultureDamanhour Branch- Alex. Univ., Egypt.

Attia, S.M. (2013). Factors influencing regreening of "Valencia" orange and preharvest tretments to degreen fruits. Ph.D. Facul. of Agri.- Damanhour Univ., Egypt.

Ben-Arieh, H. and S. Guelfat-Reich. (1975). Early ripening of nectarines induced by succinic acid 2,2-dimethyl hydrazide (SADH) and 2- chloroethylphosphonic acid (CRPA). Coll. Int.CNRS.Paris.No.238:109-113.

Blazek, J. (2004). A survey of the genetic resources used in plum breeding. In VIII International Symposium on Plum and Prune Genetics, Breeding and Pomology. pp. 31-45.

Calvo Villegas, I. (2009). El cultivo del ciruelo (Prunus doméstica). Boletín técnico (9).

Cheng, Y., Liu, L., Yuan, C., \& Guan, J. (2015). Molecular Characterization of Ethylene-Regulated Anthocyanin Biosynthesis in Plums during Fruit Ripening. Plant Molecular Biology Reporter, 1-9.

Cowan, A.K. (2009). Plant growth promotion by 18:0-lysophosphatidylethanolamine involves senescence delay. Plant Signaling and Behav. 4:324-327.

Crisosto, G.M., Crisosto, C.H., Echeverría, G., Puy, J., (2007) Segregation of plum and pluot cultivars according to their organoleptic characteristics. Postharvest Biol.Technol. 44, 271-276.

Díaz-Mula, H.M., Zapata, P.J., Guillén, F., Martínez-Romero, D., Castillo, S., Serrano, M.,Valero, D., (2009). Changes in hydrophilic and lipophilic antioxidant activity and related bioactive compounds during postharvest storage of yellow and purple plum cultivars. Postharvest Biol. Technol. 51, 354-363.

Drake,-S-R; Elfving,-D-C; Drake,-M-A; Eisele,-T-A; Drake,S-L; Visser,-D-B. (2006). Effects of aminoethoxyvinylglycine, ethephon, and 1methylcyclopropene on apple fruit quality at harvest and after storage. HortTechnology 16(1): 16-23.

El-Sharkawy I, Kim WS, El-Kereamy A, Jayasankar S, Svircev AM, Brown DCW. (2007). Isolation and characterization of four ethylene signal transduction elements in plums (Prunus salicina L.). J. Exp. Bot. 58:3631-3643.

Farag, K. M and Palta, J. P. (1989). Enhancing effectiveness of ethephon on cranberry fruit by natural products, (ethanol, urea and lysophosphatidylethanolamine (LPE)). Proceedings of the 16th Annual Meeting of the Amer. Soc. for Plant Phys.
Farag, K. M., Palta, J. P. (1991b). Use of lysophosphatidylethanolamine, a natural lipid, to delay tomato fruit and leaf senescence. HortScience, 26: 67. (Abstr.)

Farag, K. M. and Palta J. P. (1991c). Enhancing ripening and keeping quality of apple and cranberry fruits using lysophosphatidylethanolamine, a natural lipid. HortScience, 26: 67. (Abstr.)

Farag, K. M. and Palta, J. P. (1993a). Use of lysophosphatidylethanolamine, a natural lipid, to retard tomato leaf and fruit senescence. Physiologia Plantarum, 87: 515-521.

Farag, K. M. and Palta, J. P. (1993b). Use of natural lipids to accelerate ripening and enhance storage life of tomato fruit with or without ethephon. HortTechnology, 3: 6265.

Farag, K. M., Haikal, A. M. and Attia, S. M. (2010). Effect of some preharvest treatments on quality and ripening of "Canino" apricot fruits. II. Applications at color initiation. J. Agric and Env. Sci. Dam. Univ., Egypt. Vol. 9 (3) 36-67.

Farag, K. M., Haikal, A. M. and Attia, S. M. (2011). Effect of some preharvest treatments on quality and ripening of "Canino" apricot fruits.III. Developmental aspects and the shelf life of apricots. J. Agric and Env. Sci. Dam. Univ., Egypt. Vol. 10 (1) 41-72.

Farag, K. M., Haikal, A. M. and Attia, S. M. (2012). Effect of some Preharvest treatments on quality and ripening of "Canino" apricot fruits. I. Applications at pit hardening. Australian J. of Basic and Applied Sci. 6 (7): 518-531.

Fuleki, T. and F. J. Francis. (1968). Quantitative methods for anthocyanins. 1- Extraction and determination of total anthocyanin in cranberries. J of Food Sci., 33:72-77.

Gil, M. I., Tomás-Barberán, F. A., Hess-Pierce, B., \& Kader, A. A. (2002). Antioxidant capacities, phenolic compounds, carotenoids, and vitamin $\mathrm{C}$ contents of nectarine, peach, and plum cultivars from California. J. of Agric. and Food Chemistry, 50(17): 4976-4982.

Guerra, M., Casquero, P.A., (2008). Effect of harvest date on cold storage and postharvest quality of plum cv. Green Gage. Postharvest Biol. Technol. 47, 325-332.

Hong, J. H., Altwies, J. R., Guelzow, M. and Palta, J. P. (2002). The influence of lysophos-phatidylethanolamine, a natural lipid, ethylene production and ACC oxidase activity on mature green vs. red tomatoes. Acta Horticulturae. (Abstr.)

Hong, J.H. (2008). Lysophosphatidylethanolamine treatment stimulates ripening in table grape. Kor. J. Hort. Sci. Technol. 26:139-143.

Hong, J.H., G.H. Chung, and A.K. Cowan. (2009a). Delayed leaf senescence by exogenous lysophos-phatidylethanolamine: Towards a mechanism of action. Plant Physiol. Biochem. 47:526-534.

Hong, J.H., G.H. Chung, and A.K. Cowan. (2009b). Lysophosphatidylethanolamine- enhanced phenylalanine ammonia-lyase and insoluble acid invertase in isolated radish cotyledons. Plant Growth Regul. 57:69-78.

Hong, J.H., S.K. Hwang, and G.H. Chung. (2008). Influence of lysophosphatidylethanolamine on reactive oxygen species, ethylene biosynthesis, and auxin action in plant tissue. Kor. J. Hort. Sci. Techol. 26:209-214.

Huybrechts,-C-J-G; Deckers,-T; Valcke,-R. (2003). Predicting fruit quality and maturity of apples by fluorescence imaging: effect of ethylene and AVG. ActaHorticulturae (599): 243-247.

Kader, A. A. (2003). A perspective on postharvest horticulture. HortScience 38(5), 1004-1008. 
Kang, C. K., Yang, Y. L., Chung, G. H. and Palta, J. P. (2003). Ripening promotion and ethylene evolution in red pepper (Capsicum annuum) as influenced by newly developed formulations of a natural lipid, lysophosphatidylethanolamine. Acta Horticulturae. 28: 317-322.

Kaur, N. and J.P. Palta. (1997). Postharvest dip in a natural lipid, lysophosphatidylethanolamine, may prolong vase life of Snapdragon flowers. HortScience 32:888-890.

Kim, D.O., Chun, O.K., Kim, Y.J., Moon, H.Y. and Lee, C.Y. (2003). Quantification of polyphenolics and their antioxidant capacity of fresh plums. J. Agric. Food Chem. 51, 6509-6515.

Lichtenthaler,H.K.,and A. R. Wellburn. (1985). Determination of total carotenoids and chlorophylls a and $\mathrm{b}$ of leaf in different solvents, Biol. Soc. Trans. 11: 591-592.

Louw, E. D., \& Theron, K. I. (2012). Volatile dynamics during maturation, ripening and cold storage of three Japanese plum cultivars (Prunus salicina L.) Postharvest Biology and Technology, 70, 13-24.

Manganaris, A. G., A. R. Vicente., C. H. Crisosto and John M. L. (2008). Effect of delayed storage and continuous ethylene exposure on flesh reddening of 'Royal Diamond' plums. J. Sci. Food. Agric. 88:2180-2185.

Manuela, A. C., G. Campeanu and G. Neata. (2012). Studies concerning the extraction of chlorophyll and total carotenoids from vegetables. Romanian Biotechnological Letters, Vol. 17, No.5.

Martínez-Romero, D., Dupille, E., Guillén, F., Valverde, J. M., Serrano, M., \& Valero, D. (2003). 1Methylcyclopropene increases storability and shelf life in climacteric and nonclimacteric plums. Journal of Agricultural and Food Chemistry, 51(16): 4680-4686.

Maxfield, F.R., and Tabas, I. (2005). Role of cholesterol and lipid organization in disease. Nature 438: 36-45.

Murray, X. J., Holcroft, D. M., Cook, N. C., \& Wand, S. J. (2005). Postharvest quality of 'Laetitia'and 'Songold'(Prunus salicina Lindell) plums as affected by preharvest shading treatments. Postharvest Biology and Technology, 37(1), 81-92.

Mustapha, Y and Babura,S. R. (2009). Determination of carbohydrate and $\beta$-carotene content of some vegetables consumed in Kano metropolis, Nigeria. Bayero J. of Pure and Applied Sci., 2(1): 119-121.

Özgen, M., K.M. Farag, S. Özgen, and J.P. Palta. (2004). Lysophosphatidylethanolamine accelerates color development and promotes shelf life of cranberries. HortScience 40:127-130.

Özgen, M., S. Park, and J.P. Palta. (2005).Mitigation of ethylene promoted leaf senescence by a natural lipid, lysophosphatidylethanolamine. HortScience40:11661167.

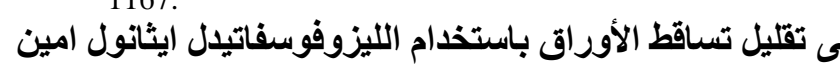

Özgen, M., Sedat Serçe, Yaşar Akça, and Ji Heun Hong. (2015). Lysophosphatidylethanolamine (LPE) improves fruit size, color, quality and phytochemical contents of sweet cherry cv. '0900 Ziraat'. Kor. J. Hort. Sci. Technol. 33(2):196-201.

Roberto, S.R., Marinho de Assis, A., Yamamoto, L.Y., Miotto, L.C.V., Sato A. J., Renata, K. and Werner, G. (2012). Application timing and concentration of abscisic acid improve colour of 'Benitaka' table grape. Sci. Hort., 142: 44 - 48.

Rozo-Romero, L. X, Javier Giovanni Álvarez-Herrera, and Helber Enrique Balaguera-López. (2015). Ethylene and changes during ripening in Horvin' plum (Prunus salicina Lindl.) fruits. Agronomía Colombiana 33(2), 228-237.

Ryu, S.B., B.H. Karlsson, M. Özgen, and J.P. Palta. (1997). Inhibition of phospholipase D by lysophosphatidylethanolamine, a lipid-derived senescence retardant. Proc. Natl. Acad Sci 94:1271712721.

SAS (2000). JMP: User's Guide, Version 4; SAS Institute, Inc.: Cary, NC, USA.

Smith, F. (1956). Colorimetric method for determination of sugar and related substance. Analytical Chemistry, 28: 350-356.

Snedecor, G. W. and W. G. Cochran. (1980). Statistical Methods. 6th Ed. Iowa State Univ. Press, Ames, Iowa. USA.

Sylvestre, I. and A. Paulin, (1987). Effect of ethylenic rise on the breakdown and synthesis of membrane lipids during the senescence in cut carnations (Dianthus caryophyllus L.) cv. Ember. C.R. Acadsci. ser. III. 305:331-334.

Vizzotto, M., Cisneros-Zevallos, L., Byrne, D. H., Ramming, D. W., \& Okie, W. R. (2007). Large variation found in the phytochemical and antioxidant activity of peach and plum germplasm. Journal of the Amer. Soc. for Hort. Sci., 132(3): 334-340.

Zienab F.R. Ahmed, Jiwan P. Palta., (2015). A postharvest dip treatment with lysophosphatidylethanolamine, a natural phospholipid, may retard senescence and improve the shelf life of banana fruit. HortScience. 50:1035-1040.

Zuzunaga, M., Serrano, M., Martínez-Romero, D., Valero, D., \& Riquelme, F. (2001). Comparative study of two plum (Prunus salicina Lindl.) cultivars during growth and ripening. Food Science and Technology International, 7(2): 123-130.

\footnotetext{
وحامض الأوليك كريم محمد فرج و سمعيد محمد عطية.

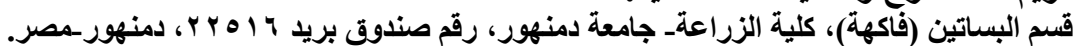

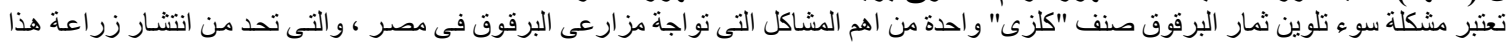

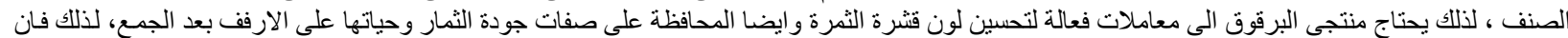

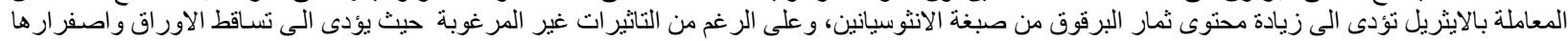

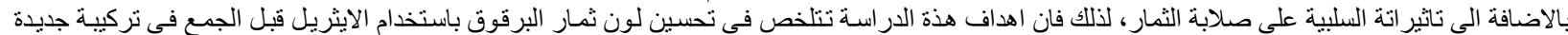

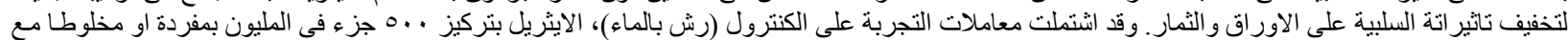

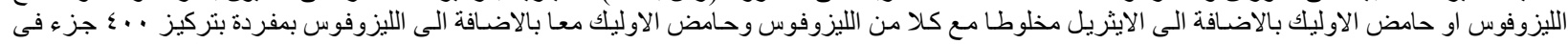

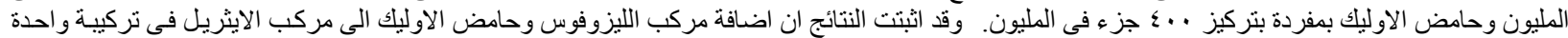

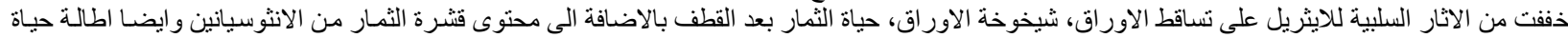

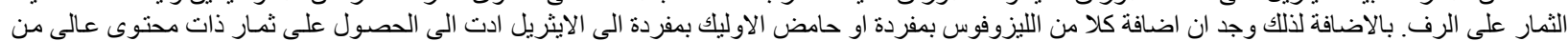

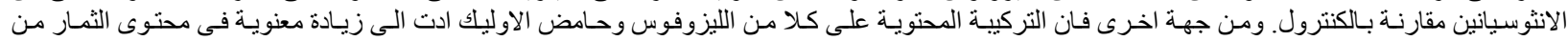

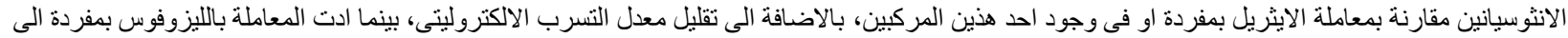

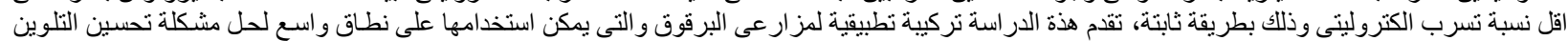

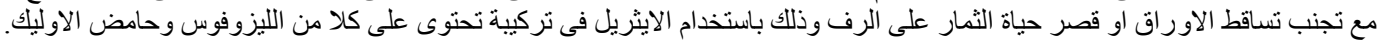

تحسين لون واطالة حياة ثمار البرقوق على الرف بالاضافة الت 